Tropical Journal of Pharmaceutical Research April 2012; 11 (2): 193-200

(c) Pharmacotherapy Group,

Faculty of Pharmacy, University of Benin, Benin City, 300001 Nigeria.

All rights reserved.

Research Article

http://dx.doi.org/10.4314/tjpr.v11i2.4

\title{
Screening and Mechanism of Trapping Ligand Antagonist Peptide for Chemokine Receptor US28 of Human Cytomegalovirus
}

\author{
Hongai Liu, Hanxiao Sun*, Lu Li, Xuemei Mo, Xiuying Li and Guang \\ Zhang \\ Institute of Genomic Medicine, College of Pharmacy, Jinan University, Guangzhou 510632, China
}

Abstract

Purpose: The aim of the present study was to develop peptide $\mathrm{H} 9$ as an efficient antagonist of human cytomegalovirus (HCMV) chemokine receptor US28.

Methods: US28 gene was amplified from HCMV, and a stable expression system was constructed using NIH/3T3 cells. Interaction between peptide H9 and receptor US28 was tested by enzyme-linked immunosorbent assay. Flow cytometry was used to determine intracellular concentrations of $\mathrm{Ca}^{2+}$, and the possible role of $\mathrm{H9}$ as an antagonist was evaluated by anti-viral experiments.

Results: $\mathrm{H} 9$ interacts with the US28 receptor and prevents an increase of $\mathrm{Ca}^{2+}$ resulting from an interaction of chemokine with its receptor. Anti-viral assays showed that $\mathrm{H} 9$ could inhibit cytopathic effects of HCMV. AD169 infection $\left(E C_{50}=0.46 \mathrm{ng} / \mathrm{ml}\right)$, and the production of pp65 antigen were strongly inhibited with an $E C_{50}$ value of $0.34 \mathrm{ng} / \mathrm{ml}$.

Conclusion: The results demonstrate that H9 is an antagonist of US28, suggesting a possible role as a treatment for HCMV.

Keywords: Human cytomegalovirus, US28, Peptide H9, Trapping receptor/ligand, Antagonist

*Corresponding author: Email: sunhx718@yahoo.com.cn, liuaihongny@163.com; Tel: +86-020-38375022 


\section{INTRODUCTION}

Human cytomegalovirus (HCMV) is a widespread human virus that can infect immuno-compromised patients (e.g., HIVinfected patients, organ transplant recipients and newborn babies). Approximately $50-80$ $\%$ of adults in North America and Europe, and approximately $100 \%$ of adults in Asia and Africa, test seropositive for HCMV [1, 2]. During the last 20 yrs, HCMV infection has increased with increase in the numbers of immunocompromised individuals [3]. To date, no treatment has been developed for HCMV infection.

HCMV has developed numerous strategies for evading the human immune system. Four homologs of host G-protein-coupled receptors, including US27, US28, UL33 and UL78, are expressed after HCMV infection [4]. Among the mimics, US28 is the best characterized HCMV-encoded G-proteincoupled receptor. US28 is thought to act as a CC chemokine (CK) sink, to weaken immune responses at the infection site. US28 can also regulate intercellular transfer of HCMV via binding membrane-associated CXCL1 (fractalkine). Additionally, US28-induced vascular smooth muscle cell (SMC) migration might play a key role in induction of vascular diseases [3]. Therefore, US28 is regarded as an attractive target for the development of anti-HCMV therapy.

US28 amino acid sequence is approximately $30 \%$ homologous to the mammalian $\alpha$ - and $\beta$-receptors of leukocytes [5]. Although chemokine binding by US28 is different from known mammalian $\beta$ chemokine receptors [6], it nonetheless plays an important role in $\beta$ chemokine binding and calcium signaling in HCMV infected cells [7].

To avoid synthesizing a large number of peptides, bioinformatic methods were used in a previous study to predict the $\mathrm{N}$-terminal active site and transmembrane domain of US28 [8] and a target synthetic polypeptide H22 was selected corresponding to residues
14-35 near the $\mathrm{N}$-terminal region of US28 (Phe-Asp-Tyr-Asp-Glu-Asp-Ala-Th-Pro-CysVal-Phe-Thr-Asp-Val-Leu-Asn-Gln-Ser-LysPro-Val). H22 exhibited no chemotaxic effect and could block the binding between physiologically active chemokine and receptor. Using a random phage library including 25 chemokines, 30 positive clones were selected. An enzyme-linked immunosorbent assay (ELISA) involving competitive blocking and competitive inhibition was used to identify clone No.5, which simulated human macrophage inflammatory factor- $1 \beta$ (hMIP-1 $\beta$ ) when combined with synthetic peptide $\mathrm{H} 22$.

The aim of the present study was to design a peptide containing 9 amino acids (H9) on the basis of the structure of $\mathrm{H} 22$, and further evaluate its potential as an efficient antagonist of US28.

\section{EXPERIMENTAL}

\section{Screening, modification and synthesis of peptide $\mathrm{H} 9$}

A lead peptide was obtained by the phage display technique, composed of seven amino acids (LNAHCAL). After analysis using ProtParam, the target sequence VLNAHCALH (H9) was chosen. The properties of $\mathrm{H} 9$ were as follows: molecular weight, 977.1; isoelectric point, 6.88; good stability under standard $\mathrm{pH}$ and stable expression in vitro. The purity was determined using high-performance liquid chromatography. The molecular weight of $\mathrm{H} 9$ was determined using mass spectrometry.

\section{Construction of cell lines US28-NIH/3T3 and ORF74-NIH3T3}

After infection of strain AD169 (HCMV) for 72 $\mathrm{h}$, the host cell with virus liquid was boiled for $10 \mathrm{~min}$, and centrifuged at $12,000 \mathrm{rpm}$ for 5 min. The supernatant was used for the PCR reaction. Primers of US28 were: 5'GCCAAGCTTATGACACCGACGACGA-3' for 
the upstream primer, and 5'TGCTCTAGATTACGGTATAATTTGTGAGA CG-3' for the downstream primer. After purification, PCR products were digested with Xba1 and Hind III restriction enzymes, and ligated into plasmid pcDNA3.1. Using calcium phosphate, the US28 gene was transferred into NIH/3T3 cells. Recombinant clones were screened using culture medium containing $400 \mu \mathrm{g} / \mathrm{ml}$ G-418 disulfide. Cell line ORF74$\mathrm{NIH} / 3 \mathrm{~T} 3$ was constructed in a similar manner. DNA was extracted from cell line BCBL infected with HHV8. ORF74 gene was amplified with the following primers: 5'GTGGGATCCGATTACCCTGTTGTTAGCAC $A-3$ ' for the upstream primer, and 5'AGCGTCGACTTATGTCATTTCCTGTGGAG A-3' for the downstream primer. The expression plasmid was constructed with PCR product ORF74 and expression plasmid pCEFL, then transfected into NIH3T3 cells.

\section{Binding assay of $\mathrm{H} 9$ and receptors}

Determination of calcium concentration in transfected cells

The concentration of cells was adjusted to $2 \times 10^{6} / \mathrm{ml}$. Cells were treated as follows: for the chemokine group, hMIP-1 $\beta(10 \mathrm{ng} / \mathrm{ml})$ was used; for the inhibitor group, $100 \mathrm{ng} / \mathrm{ml}$ H9 was used; for the inhibitor plus chemokine group, both hMIP-1 $\beta$ (10 ng/ml) and H9 (100 $\mathrm{ng} / \mathrm{ml}$ ) were used. After treatment for $24 \mathrm{~h}$, cells were washed twice with serum-free RPMI1640, and the density of cells was adjusted to $1 \times 10^{7} / \mathrm{ml}$. The molecular probe Fluo-3/AM was added at the final concentration of $10 \mu \mathrm{M}$. After incubation in the dark for $30 \mathrm{~min}$ at $37^{\circ} \mathrm{C}$ in a $5 \% \quad \mathrm{CO}_{2}$ incubator, cells were washed with ice cold phosphate buffered saline (PBS) once, and resuspended with $0.5 \mathrm{ml}$ PBS. Samples were tested using FACSCalibur flow cytometer after filtration. All results were expressed as mean \pm standard deviation (SD).
Cross-linking of polypeptide H9 with
receptors ORF74 and US28

Cross-linking of $\mathrm{H} 9$ with receptors ORF74 and US28 was determined using an ELISA assay. $\mathrm{H} 9$ was diluted to a concentration of $100 \mathrm{ng} / \mathrm{ml}$, and aliquots $(100 \mu \mathrm{l})$ were added into each well of a 96-well microtiter plate. Bovine serum albumin (BSA) and $10 \mathrm{ng} / \mathrm{ml}$ hMIP-1 $\beta$ were used as negative and positive controls, respectively. All assays were done in triplicate. After incubation overnight at $4^{\circ} \mathrm{C}$, unbound polypeptides were removed by washing. A PBST solution $(200 \mu \mathrm{l})$ containing $2 \%$ BSA was added to each well. Following incubation at $37^{\circ} \mathrm{C}$ for $1 \mathrm{~h}$, the plates were washed. The cell density of US28NIH3T3/ORF74-NIH/3T3 cells were adjusted to approximately $1 \times 10^{6} / \mathrm{ml}$, and $100 \mu \mathrm{l}$ was inoculated into each well of the 96-well microtiter plate. The pp65 monoclonal antibody was diluted with BSA-PBST solution at 1:2000, and $50 \mu \mathrm{l}$ was added to each well. Plates were washed after $1 \mathrm{~h}$ incubation at $37^{\circ} \mathrm{C}$. Then, the HRP-IgG was diluted with BSA-PBST solution at 1:1000, and $100 \mu \mathrm{l}$ was added to each well. Plates were washed after $1 \mathrm{~h}$ incubation at $37^{\circ} \mathrm{C}$. 3,3',5,5'tetramethylbenzidine chromogenic substrate solution $(100 \mu \mathrm{l})$ was added to each well, then incubated at $37^{\circ} \mathrm{C}$ for $10 \mathrm{~min}$. Stop solution $(50 \mu \mathrm{l})$ was added to each well to stop the reaction, and absorbance was read at $450 \mathrm{~nm}$.

\section{Anti-HCMV effect of H9}

\section{Preparation of strains}

Human embryonic lung fibroblast (HELF) cells in logarithmic phase were adjusted to a concentration of $1 \times 10^{6} / \mathrm{ml}$, and 5-10 $\mu \mathrm{HCMV}$ AD169 virus solution was added to the culture. Cytopathicity of cells was observed daily using a microscope, and the presence of pp65 in the supernatant was monitored every 3 days. Cells were tested for virus antigen (at approximately 8 days), then 
digested, centrifuged, and cryopreserved at $80^{\circ} \mathrm{C}$.

\section{Cytotoxicity detection of $\mathrm{H} 9$}

Cell toxicity of $\mathrm{H} 9$ was determined using the MTT (3-(4,5-dimethylthiazol-2-yl)-2,5-dipheny Itetrazolium bromide) assay. HELF cells in logarithmic phase were collected. The concentration of the cell suspension was adjusted to $5 \times 10^{4} / \mathrm{ml}$, and $200 \mu \mathrm{l}$ was added to wells of a 96 -well plate. After incubated at $37^{\circ} \mathrm{C}$ in $5 \% \quad \mathrm{CO}_{2}$ for $24 \mathrm{~h}$, different concentrations of $\mathrm{H} 9$ were added to triplicate wells. No treatment of the HELF cells was used as the control. After $24 \mathrm{~h}$ of further incubation, an MTT working solution was added to each well, followed by a $4 \mathrm{~h}$ incubation; thereafter, $100 \mu \mathrm{l}$ dimethyl sulfoxide was added to each well and incubated for $10 \mathrm{~min}$. The supernatant was discarded, and $100 \mu$ dimethyl sulfoxide was added to each well and incubated for $10 \mathrm{~min}$. The absorbance at $490 \mathrm{~nm}$ was measured for each well, and the survival rate of cells was calculated.

\section{Determination of virus titer after infection}

The HCMV virus suspension was diluted by a factor of 10x under sterile conditions using stock solution. HELF cells in logarithmic phase were collected after trypsin digestion, and a cell suspension was prepared using $10 \%$ fetal bovine serum in Dulbecco's modified Eagle medium. Cell suspension $(100 \mu \mathrm{l})$ was inoculated into wells of a 96-well culture plate, followed by inoculation with a dilution series of the virus. Each dilution was done in six duplicate wells. The 96-well plate was incubated at $37^{\circ} \mathrm{C}$ in $5 \% \mathrm{CO}_{2}$ for $7-10$ days. Wells exhibiting the cytopathic effect were recorded until there was no longer any further development. Infection titer was defined as $50 \%$ of cells infected (median tissue culture infective dose, TCID50). The cumulative virus infection titer was obtained by the Reed-Muench method [9].
Inhibition of HCMV- induced cell lesions by H9

Serial dilutions of $\mathrm{H} 9$ were prepared, and 100 $\mu \mathrm{l}$ was added in triplicate to wells of a 96-well plate. Negative controls included wells with cells but no virus, as well as a ganciclovirpositive control. After adding $80 \mu \mathrm{\mu l}$ suspension containing HELF cells at $4 \times 10^{5} / \mathrm{ml}$, and $20 \mu \mathrm{l}$ diluted HCMV supernatant, the final volume was $200 \mu \mathrm{l}$ for each well. The 96-well plates were incubated at $37^{\circ} \mathrm{C}$ in $5 \% \mathrm{CO}_{2}$ for 5 days, and observed for infected cell lesions and counted for the number of syncytial cytopathic effects (CPEs). CPE inhibitory rate and $\mathrm{EC}_{50}(50 \%$ effective concentration) were calculated according to the Reed-Muench method. The $\mathrm{EC}_{50}$ value was determined when $50 \%$ of the infected cells were inhibited by recombinant protein.

\section{HCMV replication inhibited by $\mathrm{H} 9$}

HELF cells infected with HCMV for $2 \mathrm{~h}$, were inoculated in triplicate into wells of a 96-well plate, then cultured at $37^{\circ} \mathrm{C}$ in $5 \% \quad \mathrm{CO}_{2}$ for 3 days. The supernatant collected after centrifugation was lysed with Triton X-100 using a volume fraction of 0.005 . To detect the inhibitory effect of the drug on HCMV replication, HCMV-pp65 antigen was determined by ELISA. The replication inhibition rate and $\mathrm{EC}_{50}$ were calculated.

\section{Data analysis}

The results are presented as mean \pm standard deviation. The data were analyzed by SPSS software version 16 . Significant differences $(p$ $<0.01$ ) between groups were determined using the unpaired Student's t-test.

\section{RESULTS}

\section{Detection and synthesis of $\mathrm{H9}$}

The purity of the $\mathrm{H} 9$ peptide, determined using high-performance liquid chromatography, was more than $98 \%$. Mass 
spectrometry was performed to verify the sequence of $\mathrm{H} 9$. The molecular weight of synthetic peptide $\mathrm{H} 9$ was calculated as 977.5, which is consistent with the theoretical value.

\section{Expression of receptor ORF74 and US28}

PCR analysis of the US28 gene demonstrated that digestion with Hind III and Xba1 produced several single bands successfully (Figure 1), which was necessary to the following transfected assay. Western blot analysis of US28-NIH/3T3 showed a very high intensity band of molecular mass $4.1 \mathrm{kDa}$ after stained $6 \mathrm{~h}$ and a low intensity at prestained (Figure 2). The results indicated the purity of US28-NIH/3T3. Two pictures of the ORF74 gene and ORF74-NIH/3T3 have been omitted.

\section{Binding of $\mathrm{H} 9$ with US28}

H9 prevents the elevation of $\mathrm{Ca}^{2+}$ induced by hMIP-1 $\beta$

Figure 3 shows representative results of $\mathrm{Ca}^{2+}$ determined by flow cytometry. The data listed in Table 1 are the mean \pm standard deviation of three independent experiments. The results showed that $10 \mathrm{ng} / \mathrm{ml}$ hMIP-1 $\beta$ can significantly increase the $\mathrm{Ca}^{2+} \quad(p<0.01)$. Pretreatment with $\mathrm{H} 9(100 \mathrm{ng} / \mathrm{ml})$ can prevent the increase of $\mathrm{Ca}^{2+}$ induced by hMIP-1 $\beta$.

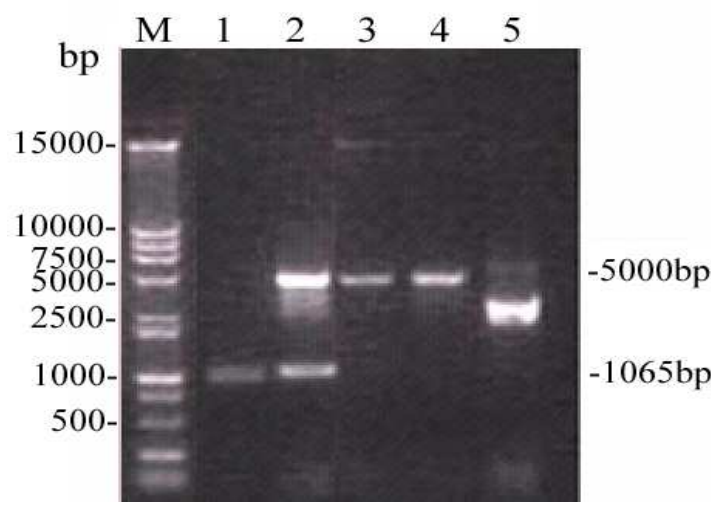

Figure 1: Digestion products of US28 and pcDNA3.1. M, molecular weight markers, 15000 and 2000 marker; 1, digestion products of US28 digested with Hind III and Xba1 after amplification; 2, double enzyme digestion products of pcDNA3.1-US28; 3, pcDNA3.1 digested with Hind III; 4, pcDNA3.1 digested with Xba1; 5, pcDNA3.1.

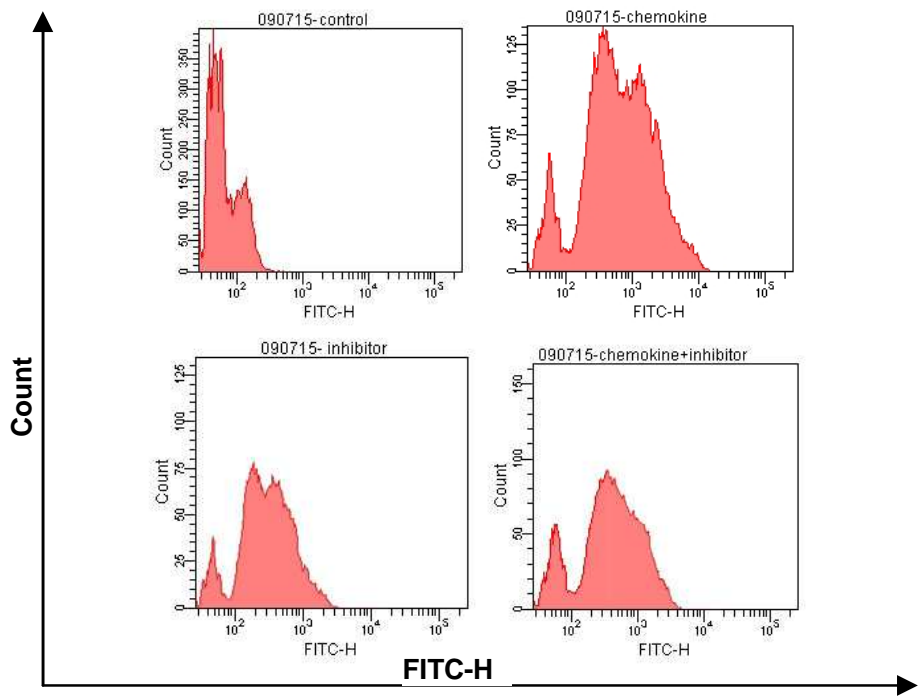

Figure 3: Flow cytometry of $\mathrm{Ca}^{2+}$ fluorescence

Flow cytometry was used for the detection of $\mathrm{Ca}^{2+}$ induced by hMIP-1 $\beta, \mathrm{H} 9$ and $\mathrm{H} 9+\mathrm{hMIP}-1 \beta$ respectively. The chemokine group (hMIP-1 $\beta$ ) can significantly increase the $\mathrm{Ca}^{2+}$, while the chemokine+inhibitor group (hMIP-1 $\beta+\mathrm{H} 9)$ can down-regulate the concentration of $\mathrm{Ca}^{2+}$. 


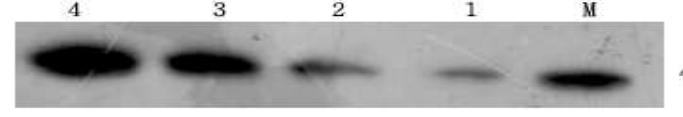

Figure 2: Western blot analysis of US28-NIH/3T3. $\mathrm{M}$, pre-stained protein marker; 1, prestained protein; 2 , poststained protein after $2 \mathrm{~h}$ staining; 3 , poststained protein after $4 \mathrm{~h}$ staining; 4, poststained protein after $6 \mathrm{~h}$ staining.

Table 1: Effect of $\mathrm{H} 9$ on $\mathrm{Ca}^{2+}$

\begin{tabular}{lc}
\hline Group & Fluorescence \\
\hline Control & $831 \pm 51$ \\
hMIP-1 $\beta(10 \mathrm{ng} / \mathrm{ml})$ & $1453 \pm 77^{\mathrm{a}}$ \\
$\mathrm{H} 9(100 \mathrm{ng} / \mathrm{ml})$ & $1074 \pm 30^{\mathrm{a}}$ \\
$\mathrm{H} 9(100 \mathrm{ng} / \mathrm{ml})+\mathrm{hMIP}-1 \beta$ & $977 \pm 87^{\mathrm{b}}$ \\
$(10 \mathrm{ng} / \mathrm{ml})$ & \\
\hline${ }^{a} p<0.01$ compared with negative control group; ${ }^{b}$ \\
$p<0.05$ compared with positive control group,
\end{tabular}

Identification of H9 and US28

The results on Table 2 show that the $A_{450}$ value after $\mathrm{H} 9$ treatment is much higher than the value of the control after BSA treatment $(p<0.01)$, indicating that a specific molecular interaction existed between $\mathrm{H} 9$ and US28/ORF74.

\section{Anti-HCMV activity of $\mathrm{H9}$}

Cytotoxicity of $\mathrm{H9}$

H9 did not exhibit significant cytotoxicity towards HELF cells, with survival rate of each treatment group more than $80 \%$. However, the positive control involving ganciclovir treatment exhibited strong cytotoxicity towards HELF cells with an $\mathrm{EC}_{50}$ value of $1.86 \mu \mathrm{g} / \mathrm{ml}$.

\section{Virus titer}

After 8 days of continuous culture, light microscopy showed lesions in cells, consistent with the replication of intracellular virus. No new changes were observed until 11 days after inoculation. At that time, $T C I D_{50}$ was calculated when virus amplification was no longer increasing. TCID 50 was $10^{-2.48} / 100$ $\mu \mathrm{l}$ for HCMV, respectively.

Table 2: ELISA assay of combinations between $\mathrm{H} 9$ and US28 or ORF74

\begin{tabular}{|c|c|c|}
\hline \multirow{2}{*}{ Group } & \multirow{2}{*}{$\begin{array}{l}\text { Concentra- } \\
\text { tion }(\mathrm{ng} / \mathrm{ml})\end{array}$} & Mean $\pm S D(n=3)$ \\
\hline & & 28 \\
\hline . & 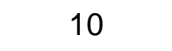 & $0.593 \pm 0.085^{\star} 0.589 \pm$ \\
\hline H9 & 00 & $0.574 \pm 0.023^{*} \quad 0.580 \pm 0.04$ \\
\hline BSA & Control & $0.108 \pm 0.016 \quad 0.112 \pm 0.014$ \\
\hline \multicolumn{3}{|c|}{$\begin{array}{l}* 0<01 \text { compared with control ; SD = standard } \\
\text { deviation }\end{array}$} \\
\hline \multicolumn{3}{|c|}{ H9 inhibition of HCMV-induced cytopathicity } \\
\hline \multicolumn{3}{|c|}{$\begin{array}{l}\text { Concentrations of peptide } \mathrm{H} 9 \text { (ranging from } \\
0.08-250 \mathrm{ng} / \mathrm{ml} \text { ) were selected for the } \\
\text { inhibition assay induced by } \mathrm{HCMV} \text {. The } \\
\text { results (not shown) indicate that } \mathrm{H} 9 \text { inhibited } \\
\text { the formation of } \mathrm{CPE} \text { in a dose-dependent } \\
\text { manner. } \mathrm{EC}_{50} \text { of } \mathrm{H} 9(0.46 \mathrm{ng} / \mathrm{ml}) \text { was greater } \\
\text { than that of the ganciclovir (GCV) group ( } 0.68 \\
\mathrm{ng} / \mathrm{ml}) \text {, i.e., positive control group. }\end{array}$} \\
\hline
\end{tabular}

\section{H9 inhibits virus replication in HCMV- infected cells}

H9 inhibited production of pp65 in HCMVinfected HELF cell culture supernatant in a dose-dependent manner. The amount of pp65 down-regulated by incubating the culture supernatants correlated with increase in the concentration of $\mathrm{H} 9$ or GCV $(0.08 \sim 250$ $\mathrm{ng} / \mathrm{ml})$. The $\mathrm{EC}_{50}$ for $\mathrm{H} 9$ was $0.34 \mathrm{ng} / \mathrm{ml}$, which was lower than the $\mathrm{EC}_{50}$ for the positive control $(0.71 \mathrm{ng} / \mathrm{ml})$.

\section{DISCUSSION}

The chemokine receptor is an attractive target for drug development, so researchers are making great efforts to study antagonists of this receptor. To date, there have been a variety of chemokine receptor antagonists entering phases of animal experiments or clinical studies [10-12]. Screening of antagonists for their ability to bind to virusencoded chemokine receptors is an important 
consideration when developing broad spectrum anti-viral therapies.

Recently, various small molecules with a similar structure to chemokines have been used as antagonists to inhibit inflammatory responses. These small molecules bind to the chemokine receptor, but do not initiate cytoplasmic signal transduction cascades. Normal physiological functions of chemokine receptors can be suppressed by these small molecule compounds. The $\mathrm{N}$-terminal region of a chemokine is an important candidate site for development of antagonists, since it initially combines with receptors to start a series of signal cascades [13]. Crump et al. developed an SDF-1 analog by modifying Lys-1 and/or Pro-2 in the $\mathrm{N}$-terminal region of SDF-1, using it as a HIV-1 receptor antagonist. [13].

Chemokine receptor US28 constitutes a class of receptors, which are similar to multiple herpes virus family members such as U12, U51 of HHV-7 and HHV-6, and ORF74 of HHV-8. Because US28 has the ability to bind various chemokines such as $\mathrm{CC}$ and $\mathrm{CXC}$, this study characterized the binding of US28 to a broad spectrum of human chemokines. On one hand, the US28 receptor can bind to a variety of human chemokines. On the other hand, a library of broad spectrum chemokine peptides can be developed to bind to the CC and CXC chemokine classes. In the present study, significant differences in absorbance were observed between the H9-treatment group and negative control BSA-treatment group, suggesting a possible interaction between "trapping ligand" polypeptide H9 with the US28 receptor. Furthermore, studies of the effect of $\mathrm{H} 9$ on intracellular $\mathrm{Ca}^{2+}$ concentration show that pretreatment with $\mathrm{H} 9$ could efficiently prevent the elevation of $\mathrm{Ca}^{2+}$ concentration induced by hMIP-1 $\beta$, which further demonstrated that $\mathrm{H} 9$ was an effective antagonist of US28. This result is supported by previous findings which showed that CC chemokines could increase the intracellular concentration of $\mathrm{Ca}^{2+}$ [14]. Given that pp65 is highly conserved in various strains of HCMV, and detection of pp65 has been considered as a standard method for monitoring the infection of HCMV [15], the inhibitory potential of $\mathrm{H} 9$ towards pp65 formation was evaluated to estimate the effect of $\mathrm{H} 9$ on HCMV replication. Our results showed that the "trapping ligand" H9 has good anti-viral activity, and inhibits replication of HCMV in a dose-dependent manner. Because US28 is similar to the chemokine receptor of other multiple herpes virus family members, H9 might also exhibit antagonistic effect towards these viruses.

An expression system for chemokine receptor US28 was successfully constructed in vitro. The binding of peptide $\mathrm{H} 9$ and US28 was confirmed, suggesting the signal blocking role of $\mathrm{H} 9$. In addition, $\mathrm{H} 9$ inhibited replication of HCMV in vivo. All these results indicate that peptide $\mathrm{H} 9$ could be a possible therapeutic antagonist for HCMV.

\section{CONCLUSION}

We characterized the peptide $\mathrm{H} 9$, which is an efficient antagonist of HCMV chemokine receptor US28. At the same time, the antiviral test showed that $\mathrm{H} 9$ has the potential to inhibit the infection of HCMV. These results demonstrate that $\mathrm{H} 9$ is an antagonist of US28, and a potential candidate for treatment of HCMV.

\section{ACKNOWLEDGEMENT}

This study was supported by the National Natural Science Foundation of China (NSFC; no. 3087221), Guangdong Province Major Projects of Key Areas [YSNo(2005)162], and Major Technology Program funded projects, Guangzhou (2005Z1-E4081).

\section{REFERENCES}

1. Wang PS, Evans AS. Prevalence of Antibodies to Epstein-Barr-Virus and Cytomegalovirus in Sera from a Group of Children in the PeoplesRepublic-of-China. J Infect Dis 1986; 153: 150 152.

2. Yow MD, White NH, Taber LH, Frank AL, Gruber

Trop J Pharm Res, April 2012;11 (2):199 
WC, May RA, Norton HJ. Acquisition of cytomegalovirus infection from Birth to 10 years: a longitudinal Serologic Study. J Pediatr 1987; 110: 37-42.

3. Soderberg-Naucler C. HCMV microinfections in inflammatory diseases and cancer. J Clin Virol 2008; 41: 218-223.

4. van Cleef KWR, Smit MJ, Bruggeman CA, Vink $C$. Cytomegalovirus-encoded homologs of $G$ protein-coupled receptors and chemokines. J Clin Virol 2006; 35: 343-348.

5. Waldhoer M, Casarosa P, Rosenkilde MM, Smit MJ, Leurs R, Whistler JL, Schwartz, TW. The carboxyl terminus of human cytomegalovirusencoded 7 transmembrance receptor US28 camouflages agonism by mediating constitutive endocytosis. J Biol Chem 2003; 278(21): 19473-19482.

6. Rosenkilde MM, Waldhoer M, Luttichau HR, Schwartz TW. Virally encoded 7TM receptors. Oncogene 2001; 20: 1582-1593.

7. Vieira J, Schall TJ, Corey L, Geballe AP. Functional analysis of the human cytomegalovirus US28 gene by insertion mutagenesis with the green fluorescent protein gene. J Virol 1998; 72: 8158-8165.

8. LI Lu, HE Tao, MO Xue-Mei, LI Xiu-Ying, ZHANG Guang, SUN Han-Xiao. Biological Functions, Screen and Identify Research on Chemokine Receptor Antagonist Encoded by US28 of Human Cytomegalovirus. Prog Biochem Biophys 2010; 37: 618-626.

9. Boshoff C, Endo Y, Collins PD, Takeuchi $Y$, Reeves $J D$, Schweickart VL, Siani MA, Sasaki TJ, Gray PW, Moore PS, Chang Y, Weiss RA. Angiogenic and HIV-inhibitory functions of KSHV-encoded chemokines. Science 1997;
278: 290-294.

10. Schaller MA, Kallal LE, Lukacs NW. A key role for CC chemokine receptor 1 in T-cell-mediated respiratory inflammation. Am J Pathol 2008; 172: 386-394.

11. Haasen D, Merk S, Seither P, Martyres D, Hobbie $S$, Heilker R. Pharmacological profiling of chemkine receptor-directed compounds using high-content screening. J Biomol Screen 2008; 13: 40-53.

12. Kiozumi K, Hojo S, Akashi T, Yasumoto K, Saiki I. Chemokine receptors in cancer metastasis and cancer cell-derived chemokines in host immune response. Cancer Sci 2007; 98: 16521658.

13. Crump MP, Gong JH, Loetscher P, Rajarathnam K, Amara A, Arenzana-Seisdedos F, Virelizier JL, Baggiolini $M$, Sykes BD, Clark-Lewis $I$. Solution structure and basis for functional activity of stromal cell-derived factor-1; dissociation of CXCR4 activation from binding and inhibition of HIV-1. Embo J 1997; 16: 6996-7007.

14. Streblow DN, Soderberg-Naucler C, Vieira J, Smith $P$, Wakabayashi E, Ruchti F, Mattison K, Altschuler $Y$, Nelson JA. The human cytomegalovirus chemokine receptor US28 mediates vascular smooth muscle cell migration. Cell 1999; 99: 511-520.

15. Cowan LS, Diem L, Brake MC, Crawford JT. Transfer of a Mycobacterium tuberculosis genotyping method, spoligotyping, from a reverse line-blot hybridiazation, membranebased assay to the Luminex multianalyte profiling system. J Clin Microbiol 2004; 42: 474-477. 